\title{
SCHEDULING CONSTRUCTION WORKS WITH ESTABLISHED WORKFORCE COST BUDGET
}

\author{
Zdzisław Hejducki, Łukasz Łodożyński ${ }^{\boxplus}$ \\ Faculty of Civil Engineering, Wrocław University of Science and Technology, Wrocław
}

\begin{abstract}
The problem presented in the article consists in optimizing the work teams working schedule at the given construction process budget. The maximum working time of particular working groups will be determined while carrying out construction works in order to fit in the fixed amount of wages. This issue was solved with regard to the limitations of the flow system - time coupling method ensuring continuity of works (TCM I). To solve the problem, a computational algorithm using matrix modelling and artificial intelligence for scheduling tasks was developed. An example from construction practice is presented which is a verification of the proposed calculation method. The work is part of the issue of time and cost analysis in optimal scheduling of construction processes.
\end{abstract}

Key words: time-cost optimization, organization of construction works, task scheduling, optimization problems

\section{INTRODUCTION}

In the article for scheduling construction works, the time coupling method (TCM) will be used. It is one of the many methods used for this purpose. Other tools used include: network planning, critical path method (CPM/PERT), line of balance (LOB), linear scheduling model (LSM), repetitive scheduling method (RSM), critical chain project management (CCPM).

The construction works are divided into working sectors (zones). Depending on its type, one single house may be one single-family house selected from the planned housing estate, a section of road selected from its entire run or another work that can be separated from the set of planned works.

The problem of scheduling construction works was analysed by the team of Mrozowicz (1997) at the
Wrocław University of Science and Technology. He introduced a division of methods due to couplings and proposed optimization methods with the use of the branch and bound method. Hejducki (2000) developed methods proposing a number of new dependencies between works. Podolski (2008) presented the development of time coupling methods in relation to task scheduling problems. Problems of this type are also found in the field of operational research, discrete optimization, discrete and combinatorial programming. Bożejko, Hejducki, Rogalska and Wodecki (2008, 2011), Rogalska, Bożejko and Hejducki (2008), Rogalska, Hejducki and Łodożyński (2011), Hejducki and Rogalska (2005, 2011) used artificial intelligence to find optimal schedules. Methods of metaheuristic evolutionary algorithms were used e.g. evolutionary algorithms, hybrid evolutionary algorithms and taboo search. 
The problem related to scheduling jobs with specialized work team was approached many authors. Marcinkowski and Pokora (2012) refers to the quality of the schedule, that is defined by underemployment of crews and misleading deadlines. Jaśkowski and Tomczak (2014) and Płoński (2015) approach to allocating resources considering the effects of task sequence. Biruk, Jaśkowski and Czernigowska (2017) regards optimal combination of subcontractors taking cost, time and quality of works into account.

The presented optimization problem is known in the theory of scheduling tasks as "no idle" (without interruption in the operation of machines). Various dedicated, exact, heuristic or metaheuristic algorithms can be used to solve the problem.

\section{FORMULATION OF THE PROBLEM}

The realization of the project requires the execution of works on $n$ independent sectors. The crews move between them, carrying out the construction works carried out in the established technological order.

Mathematical model of time coupling methods:

- the parameters of the discreet model are deterministic,

- the project consists of sectors $Z=\left\{Z_{1}, Z_{2}, Z_{3}, \ldots, Z_{i}\right.$, $\left.Z_{n}\right\}$,

- types of works: $B=\left\{B_{1}, B_{2}, B_{3}, \ldots, B_{j}, \ldots, B_{m}\right\}$,

- works sets: $P_{j}=\left\{p_{1 j}, p_{2 j}, p_{3 j}, \ldots, p_{m j}\right\}$ carried out by a set of working groups $\mathrm{B}$ on sectors $Z_{j} \in Z$.

Assumptions regarding works:

- the work cannot be interrupted,

- it is performed by one unit specialized in the execution of a given work,

- works are carried out in technological order $p_{k-1, j}<p_{k, j}<p_{k+1, j}$,

- at any one time the work brigade can only do one job or do none at all,

- at one time, only one job can be done on the sector, or it is unoccupied.

Work restrictions require that they be performed without downtime in the crews. This method of scheduling in time-coupling methods is called in the classic nomenclature, method with continuity of activities. In scheduling tasks methods it is known as "no idle". Working crews that perform their jobs moves between sites without additionally lags. It is important when contractors undertake tasks when continuity is assured.

The following symbols used in TCM:

- LT (least time) - time between the start dates of subsequent processes,

- CP (critical point) - the start date of the $j$-th process,

- LD (least distance) - time between operations in successive processes between which the selected coupling takes place,

- TT (total time) the total time of completing the task.

Determining the relationship between the preceding and the following works:

$$
\begin{aligned}
& P S=\sum_{k=1}^{i} t_{k, j}-\sum_{k=1}^{i} t_{k-1, j-1}, \\
& j=\{1,2, \ldots, m-1\}, i=\{1,2 \ldots, n\}, t_{0, j+1}=0
\end{aligned}
$$

Least time is designated as the maximum value $P S$ :

$$
L T=\max _{j} P S_{j}, j=\{1,2, \ldots, m-1\}
$$

Critical point is determined as a partial sum of time intervals at the close-up:

$C P_{j}=\sum_{l=1}^{j-1} L T_{l}, \quad C P_{l}=0$

The total time of the works complex consists of the critical point of the last process and the duration of that process:

$$
T T=C P_{m}+\sum_{i=1}^{n} t_{i, m}
$$

\section{SPECIFICATION OF ENTRY DATA}

The input data is presented in the form of input matrixes. It is an easy and intuitive way of presenting data, because each cell of the matrix represents the value of the $j$-work crew on the $i$-th sector. The matrix for the model is presented as $\mathbf{T}=\left[t_{i, j}\right]$. 
Depending on the needs, the input matrix can sometimes be filled with: the duration of the operation, costs, expenditures, duration of idles/waits, additional couplings. The structure of the input matrix for each type of data is the same. Depending on the type of input data, the following types of matrices are itemized:

- workload matrix - N [w-h]

It contains labor, material and equipment inputs given in man-hours or machine hours. These data come from schedule of the investment.

- the employment matrix - L [-]

It contains the number of employees and the number of rented equipment and machines.

- work time matrix $-\mathbf{C Z}$ [w-h]

It includes the working time of employees, rented equipment and machines during the day. The working time of each day is constant, except the last day on each sector, when the working day might be shorter. If time and cost analysis are not calculated, one working time matrix is provided. There are two ways to analyse working time and costs. Set up the minimum CZA and maximum CZB of the possible working times of individual crews on the sectors. All possible combinations of the work times of all crews are calculated. The second way is to provide a matrix of possible work times. Along with the remuneration matrix, program calculates the dependence of the duration and cost of the project on the input matrix, to which the cost of the project will be obtained depending on the input working time matrix.

There are two ways to analyse the project. The first determines the budget of the investment and its duration. Then, the possibility of optimizing the duration of the project is checked. In the second one is determined by the date of completion of the task and checking are the costs that should be incurred in order to meet the deadline. In the initial phase, the fixed investment cost is calculated, and in the optimization process the duration of the project will be shortened, so the calculation process will have to be repeated at least once in order to find a deadline no longer than the assumed date. Then select the time matrix that meets the assumptions. The calculation does not take into account the decrease in productivity as the length of working time increases.

- remuneration matrix $-\mathbf{S}\left[\mathrm{PLN} \cdot \mathrm{w}-\mathrm{h}^{-1}\right]$
Includes pay per hour of crews on a given sector. It is possible to vary the rate on each sector. In the calculation example, a fixed value will be adopted for all members of the brigade. The base working time for which the basic rate is calculated for each work team on each working sector is $8 \mathrm{~h}$. Above this time, the overtime bonus is calculated. The overtime bonus for each brigade on each sector is a $200 \%$ of the basic rate.

- matrix of working days - M [days]

Determines how many days work on the $i$-th sector is in progress. It is a function of the workload matrix $(\mathbf{N})$, crews $(\mathbf{L})$ and work time $\left(\mathbf{C M}=\frac{\mathbf{N}}{\mathbf{L} \times \mathbf{C Z}}\right)$, rounded up to full days:

\section{METHOD OF COMPUTATIONS}

In order to use the optimization methods, three types of main input matrices and optionally two types of additional input matrices are entered. The three main components are the input, employed and working time matrices, from which the input work time matrix is created. The additional two are remuneration matrix (for cost analysis) and a lag matrix (for downtime analysis). The algorithm analyses the connection of time and costs. Depending on how the cost matrix entered, the route $A$ or $B$ is selected. Models and computational experiments were created and carried out in the Mathematica computation environment.

Algorithm steps:

1. Four types of matrix are needed - inputs, working time, employees and remuneration:

a) the working time matrix consists of two matrices defining the minimum and maximum possible working time of the brigade on a given sector,

b) introduction of determined matrices of working times.

2. Matrix $\mathbf{M}$ that determines the duration of the work of the $i$-brigade on the $j$-th sector is calculated from the input, labor and labor matrix:

a) work time matrices created from the permutation of all possible working times,

b) time matrices have already been set in point $1 \mathrm{~b}$.

3. Calculation and comparison of the project duration and project costs for the non-optimized matrix $\mathbf{M}$. 
4. One variant is chosen - the costs will not change, the time will be optimized.

5. Optimization of the selected matrix $\mathbf{M}$ by Mrozowicz (1997) B\&B method.

6. Calculation the matrix of time relations with costs and obtaining diagrams.

\section{CASE STUDY}

The case study will consist of an analysis in two stages. In the first one, data will be given in the form of workload, brigade sizes, their work times and remuneration. The investment cost will be fixed. As a result of the calculations made, the working time of crew and the time of project will be determined. In the next stage, for the given input values, a time/cost analysis will conducted. It will be divided for analysis separately for each work carried out, as well as their partial sum.

The example consists of four building objects, on which four works have to be made in technological order. Input data in the form of workload, size of crew and length of work shifts are included in Tables 1-6, and the schedule created on its basis is in Figure 1. The investment cost is settled at PLN 42.500.

Table 1. Workload matrix

$\mathbf{N}=\left[\begin{array}{cccc}56 & 255 & 522 & 200 \\ 24 & 155 & 200 & 80 \\ 21 & 256 & 586 & 150 \\ 56 & 356 & 251 & 350\end{array}\right]$

Table 2. Employees matrix

$\mathbf{L}=\left[\begin{array}{llll}5 & 6 & 7 & 8 \\ 5 & 2 & 5 & 6 \\ 5 & 3 & 8 & 8 \\ 5 & 2 & 2 & 5\end{array}\right]$
Table 3. Working time of employees $A$

$\mathbf{C Z A}=\left[\begin{array}{llll}8 & 8 & 8 & 8 \\ 8 & 8 & 8 & 8 \\ 8 & 8 & 8 & 8 \\ 8 & 8 & 8 & 8\end{array}\right]$

Table 4. Working time of employees $B$

$\mathbf{C Z B}=\left[\begin{array}{cccc}8 & 8 & 8 & 8 \\ 8 & 11 & 9 & 9 \\ 8 & 8 & 8 & 10 \\ 9 & 8 & 10 & 8\end{array}\right]$

Table 5. Remuneration matrix

$\mathbf{S}=\left[\begin{array}{cccc}10 & 18 & 8 & 8 \\ 13 & 18 & 8 & 8 \\ 15 & 12 & 8 & 10 \\ 10 & 15 & 12 & 8\end{array}\right]$

Table 6. Working time span

$\mathbf{C Z}=\left[\begin{array}{cccc}8 & 8 & 8 & 8 \\ 8 & 8-11 & 8-9 & 8-9 \\ 8 & 8 & 8 & 8-10 \\ 8-9 & 8 & 8-10 & 8\end{array}\right]$

The time span matrix (Table 6) is created from CZA and CZB consisting of the minimum and maximum working times. Then all possible combinations of working times, in this case 288 are calculated. From the matrixes $\mathbf{N}, \mathbf{L}, \mathbf{C Z}$ and all possible combinations of working times (Table 6) are calculated as M. Together with the matrix $\mathbf{S}$, a matrix of possible durations of the project will be calculated together with the corresponding costs. Established costs: PLN 42.500. 


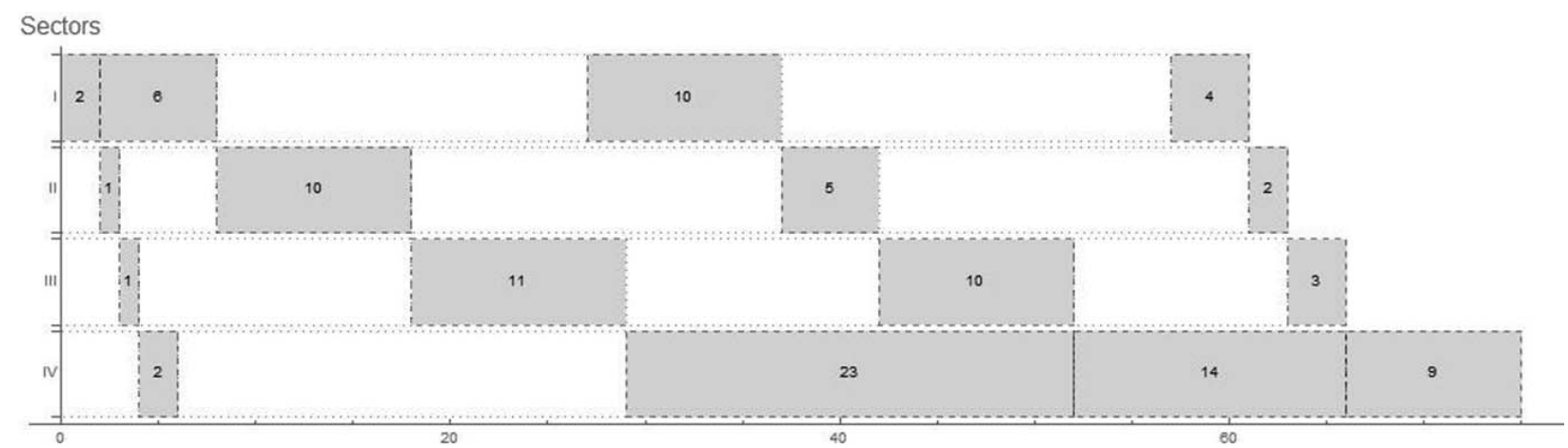

Fig. 1. Project schedule for input data

Table 7. Times and costs matrix

$\left[\begin{array}{cccccccccccc}\text { No } & 1 & 2 & 3 & \ldots & 74 & \ldots & 80 & 81 & \ldots & 286 & 288 \\ \text { [days] } & 77 & 77 & 77 & \ldots & 74 & \ldots & 74 & 74 & \ldots & 72 & 72 \\ \text { [PLN] } & 41.360 & 41.360 & 41.552 & \cdots & 42.008 & \ldots & 42.448 & 42.872 & \cdots & 44.264 & 44.456\end{array}\right]$

The matrix at which costs will not be exceeded that has the shortest completion time is selected, along with its corresponding duration of the project. The cost is PLN 42.008 and the corresponding time is 74 days (Table 7). These values are obtained in 74 combination, which is listed in Tables 8 and 9.

Table 8. Working time of employees

$$
\mathbf{C Z}=\left[\begin{array}{llll}
8 & 8 & 8 & 8 \\
8 & 8 & 8 & 8 \\
8 & 8 & 8 & 8 \\
8 & 8 & 9 & 8
\end{array}\right]
$$

Table 9. Input work times matrix

$$
\mathbf{M}=\left[\begin{array}{cccc}
2 & 6 & 10 & 4 \\
1 & 9 & 5 & 2 \\
1 & 11 & 10 & 3 \\
2 & 23 & 14 & 9
\end{array}\right]
$$

Then the optimization of the duration of the project is carried out using classic approach [17] with branch and bound method, which allows to shorten it to 62 days. The matrix containing the optimized order of works is in Table 10, and the schedule created on its basis in Figure 2.

Table 10. Optimized work time matrix

$\mathbf{M}=\left[\begin{array}{cccc}2 & 6 & 10 & 4 \\ 2 & 23 & 14 & 9 \\ 1 & 11 & 10 & 3 \\ 1 & 9 & 5 & 2\end{array}\right]$

The developed software allows analysis of the development of the construction project costs. Four possible types may be generated:

- partial costs of individual works - show investment expenditures spent on a selected contractor's gang at a particular day, 


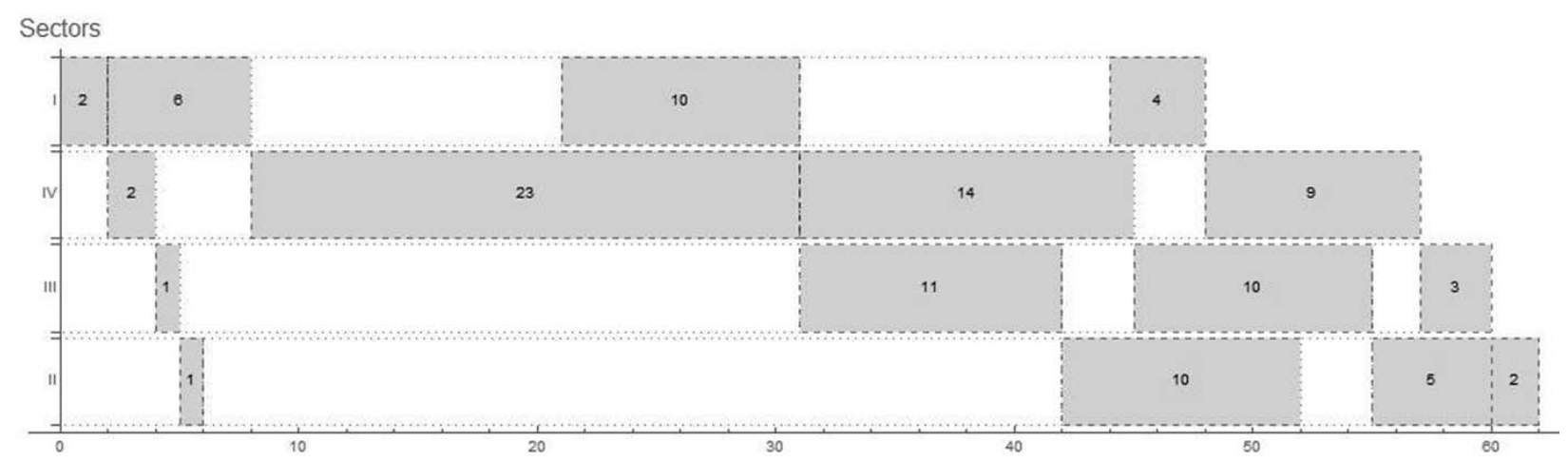

Fig. 2. Project schedule for optimized data

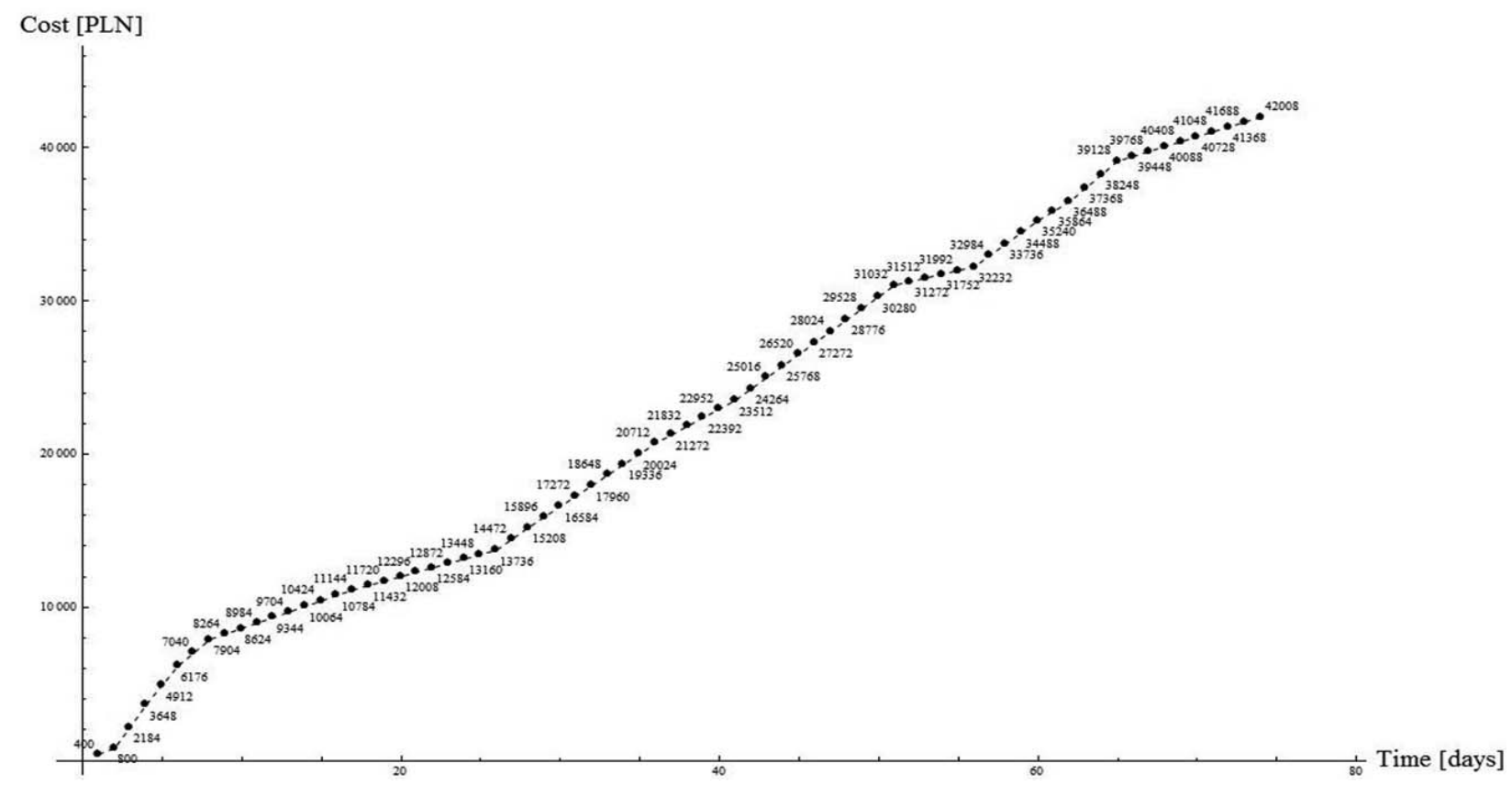

Fig. 3. Total costs of all works for non-optimized schedule

- total costs of individual works - show investment expenditures spent on a selected contractor's gang from the first day of work to the selected day,

- partial costs of all works - show investment expen- ditures spent on all contractor's gangs on a particular day,

- total costs of all works - show investment expenditures spent on all contractor's gangs from the first day of work to the selected day (Figs. 3, 4). 


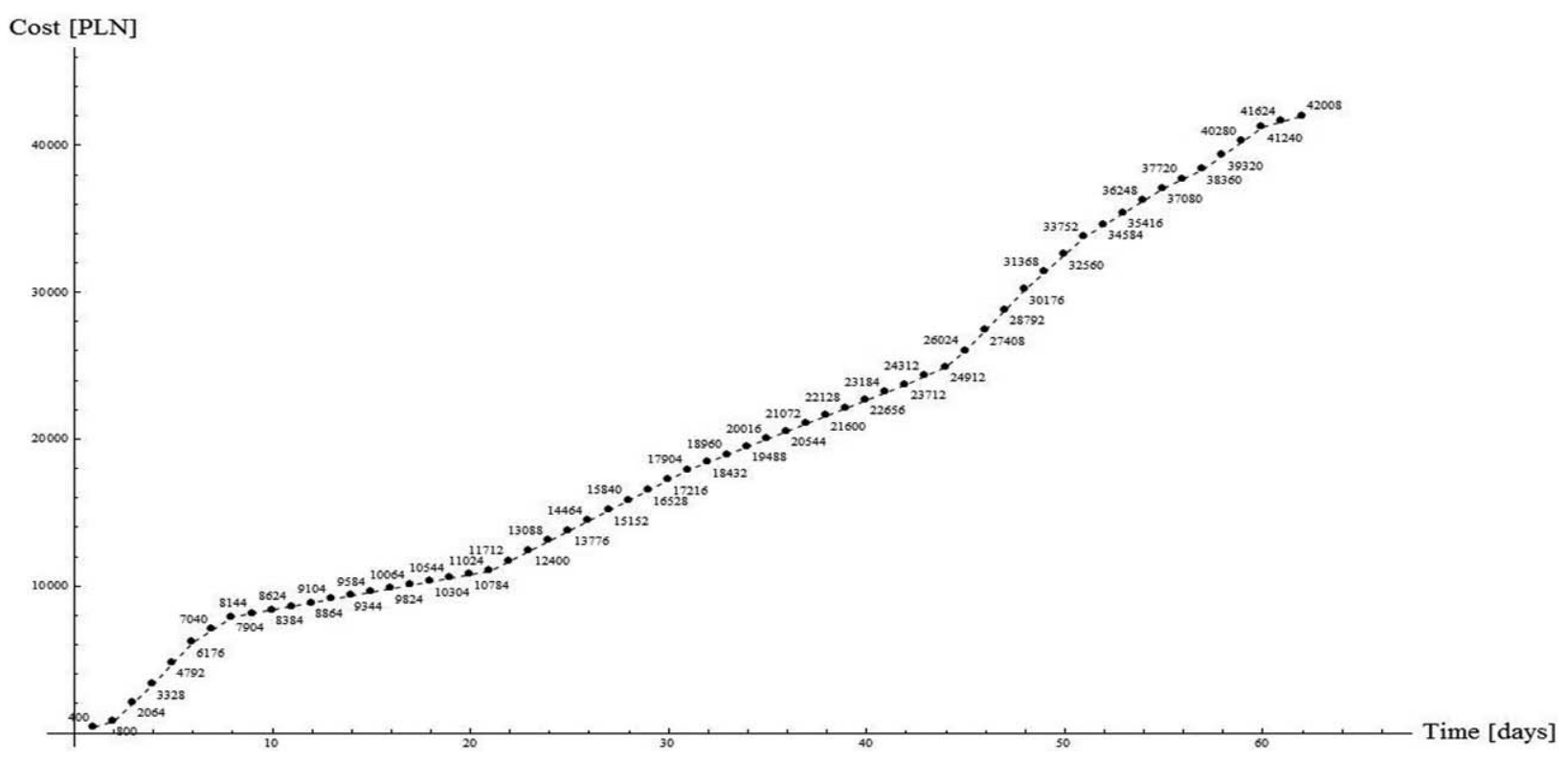

Fig. 4. Total costs of all works for optimized sche- dule

\section{SUMMARY}

The article presents the use of a time coupling method for scheduling construction works in order to rationally select the time of work of contractors gangs. A budget for the execution of works was assumed and the durations of working shifts were chosen so that the remuneration did not exceed the assumed ones. The schedule was created using TCM I, ensuring continuity of work teams. Then, the work schedule was optimized using the branch and bound method, thus shortening the time of its competition. The article is part of the authors research on time-cost optimization in the planning of construction projects.

\section{REFERENCES}

Biruk, S., Jaśkowski, P. \& Czarnigowska, A. (2017). Minimizing Project Cost by Integrating Subcontractor Selection Decisions with Scheduling. IOP Conference Series: Materials Science and Engineering, 245, 1-7. DOI: $10.1088 / 1757-899 X / 245 / 7 / 072007$
Bożejko, W., Hejducki, Z., Rogalska, M. \& Wodecki, M. (2008). Analiza szczególnej zależności typu czas/koszt $\mathrm{z}$ zastosowaniem metod sztucznej inteligencji. In A. Łapko (Ed.), Problemy naukowo-badawcze budownictwa. Vol. V. Zagadnienia materiałowo-technologiczne infrastruktury i budownictwa (pp. 157-164). Białystok: Wydawnictwo Politechniki Białostockiej.

Bożejko, W., Hejducki, Z., Rogalska, M. \& Wodecki, M. (2011). Scheduling of construction projects with a hybrid evolutionary algorithm's application. In E. Kita (Ed.), Evolutionary algorithms (pp. 295-308). Rijeka: InTech.

Hejducki, Z. \& Rogalska, M. (2005). Metody sprzężeń czasowych TCM. Przeglad Budowlany, 2, 38-45.

Hejducki, Z. \& Rogalska, M. (2011). Time coupling methods. Construction scheduling and time/cost optimization. Wrocław: Oficyna Wydawnicza Politechniki Wrocławskiej.

Hejducki, Z. \& Rogalska, M. (2017). Harmonogramowanie procesów budowlanych metodami sprzężeń czasowych. Lublin: Wydawnictwo Politechniki Lubelskiej.

Hejducki, Z. (2000). Sprzężenia czasowe w metodach organizacji złożonych procesów budowlanych. Prace Nau- 
kowe Instytutu Budownictwa Politechniki Wrocławskiej. Monografie, 77 (34), 126.

Jaśkowski, P. \& Tomczak, M. (2014). Assignment problem and its extensions for construction project scheduling. Technical Transactions. Civil Engineering, 2-B, 241-248.

Marcinkowski, R. \& Pokora, M. (2012). Harmonogramowanie pracy specjalistycznych zespołów roboczych w wieloobiektowych przedsięwzięciach budowlanych. Zeszyty Naukowe Politechniki Rzeszowskiej. Budownictwo i Inżynieria Środowiska, 3/12/III (283), 89-96.

Mrozowicz, J. (1997). Metody organizacji procesów budowlanych uwzględniajace sprzężenia czasowe. Wrocław: Dolnośląskie Wydawnictwo Edukacyjne.

Płoński, M. (2015). Application of the work breakdown structure in determining cos buffers in construction schedules. Archives of Civil Engineering, 1, 147-161.

Podolski, M. (2008). Analiza nowych zastosowań teorii szeregowania zadań $w$ organizacji robot budowlanych (PhD thesis). Oficyna Wydawnicza Politechniki Wrocławskiej, Wrocław.

Rogalska, M., Bożejko, W. \& Hejducki, Z. (2008). Time/ /cost optimization using hybrid evolutionary algorithm in construction project scheduling. Automation in Construction, 18, 24-31.

Rogalska, M., Hejducki, Z. \& Łodożyński, Ł. (2011). Harmonogramowanie liniowych procesów budowlanych z uwzględnieniem metody Branch \& Bound. In Z. Tokarski (Eds.), Organizacja przedsięwzięć budownictwa drogowego (pp. 107-118). Bydgoszcz: Rekpol.

\section{HARMONOGRAMOWANIE ROBÓT BUDOWLANYCH Z UWZGLĘDNIENIEM USTALONEGO BUDŻETU KOSZTÓW}

\section{STRESZCZENIE}

Przedstawione $\mathrm{w}$ artykule zadanie polega na optymalizacji harmonogramu pracy brygad roboczych przy zadanym budżecie procesu budowlanego. Ustalony zostanie maksymalny czas pracy poszczególnych grup roboczych przy wykonywaniu robót budowlanych tak, aby zmieścić się w ustalonej kwocie wynagrodzeń. Zagadnienie to rozwiązano z uwzględnieniem ograniczeń systemu potokowego - metody sprzężeń czasowych zapewniającej ciągłość prowadzenia robót (TCM I). Do rozwiązania postawionego problemu opracowano algorytm obliczeniowy wykorzystujący modelowanie macierzowe i metodę sztucznej inteligencji do szeregowania zadań. Przedstawiono przykład z praktyki budowlanej będący weryfikacją zaproponowanej metody obliczeniowej. Praca stanowi część zagadnienia dotyczącego analizy czasu i kosztów w optymalnym harmonogramowaniu procesów budowlanych.

Słowa kluczowe: optymalizacja czasowo-kosztowa, harmonogramowanie robot budowlanych, szeregowanie zadań, optymalizacja problemów 